\title{
The Difference of Concentration Calcium on Human Breast Milk between Good Nutrition Status and Chronic Energy Loss Postpartum Mothers
}

\section{St. Surya Indah Nurdin ${ }^{1 *}$, Andi Wardihan Sinrang ${ }^{2}$, Nasrudin $\mathbf{A M}^{3}$}

${ }^{1}$ Midwifery Department, Faculty of Health Sciences, Muhammadiyah University of Gorontalo, Indonesia

${ }^{2}$ Faal, Faculty of Medicine, Hasanuddin University, Indonesia

${ }^{3}$ Obstetrics and Gynecology, Faculty of Medicine, Indonesian Muslim University, Indonesia

\section{Driginal Research Article \\ *Corresponding author St. Surya Indah Nurdin \\ Article History \\ Received: 10.05 .2018 \\ Accepted: 26.05.2018 \\ Published: 30.05 .2018 \\ DOI: \\ 10.21276/haya.2018.3.5.6}

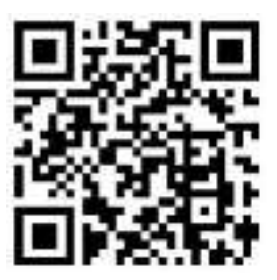

Abstract: The research aimed to find out the difference in calcium concentration in breast milk between the good nutritional status and Chronic Energy deficiency in postpartum mothers. The research was the Cross Sectional design research type. The samples are 40 people who were chosen using the purposive sampling technique, and who met inclusive criteria. The samples were collected. Fourteen days after giving the researcher, they came to the respondent's house to measure BB, LILA and 24 hours foodrecall and milked $3 \mathrm{cc}$, done by the researcher, and will check their breast milk through laboratory test using Colorimetric Assay. The data with not normal distributed were tested using the statistical shapiro-wilk test with the resultof $\alpha>0,05$. The analytical test used Mann Whitney and Chi-Square test.The research indicated that there was a very significant difference of calcium concentration between postpartum the mothers with good nutrition status and the mother chronic energy deficiency with $\mathrm{p}$ value $=0.025(\mathrm{p}<0.05)$. The research also revealed thet postpartum mothers who experienced the decrease of low concentration (median $166.7 \mathrm{mg} / \mathrm{L}$ ) 7.0 times more risk to experience the deficiency of cronic energy compared to the mother with postpartum good nutrition status.

Keywords: Calcium Concentration, Breast Milk, Nutritional Status, Foodrecall, Postpartum.

\section{INTRODUCTION}

The World Health Organization (WHO), the United Nations Childtren's Fund (UNICEF) and the Indonesian Department of Health through the Decree of the Minister of Health No.450 / Men.Kes / SK / IV / 2004 dated April 7, 2004 have established recommendations for breastfeeding ) because it is considered as the best source of nutrition for newborns for the first six months because of the very high quality and quantity. Breast milk is a gold standard for babies because it contains important substances in its growth and development $[1,2]$.

A healthy breastfeeding reduces mortality, mortality, morality and boosts immunity for optimal growth and development of children under five [3-6]. South Sulawesi's 2015 Nutrition Assessment Report (PSG) shows below that most children aged 0-5 months get breast milk alone $(39.1 \%)$. The condition shows that as many as $60.9 \%$ of children aged $0-5$ months are not breastfed, this means that there are still many babies who have not been breastfed. Based on PSG report of South Sulawesi province in 2015 shows that the older the toddler age the higher the proportion of nutritional problems is supposedly caused by the accumulation of nutritional problems since infant age where the nutritional status of infants $0-5$ months $9 \%$ nutritional status is very thin, $10.9 \%$ malnutrition status, $11.6 \%$ very short [7].

Nutritional status of breastfeeding mothers plays an important role for breastfeeding success, whose indicators are measured by the duration of exclusive breastfeeding, infant growth and nutritional stutus in post-nursing [8]. Mothers with sufficient nutritional status will stockpile the nutrient food reserves in the body that are used to offset the needs during lactation. It is very important for the adaptation process to the baby anatomy and physiology changes that lasted for the first month [9].

Nutritional status in pregnancy and breastfeeding is one of the most important determinants of women's health and next-generation health. The current concern focuses on the nutritional problems of pregnancy and breast-feeding because of the high maternal and infant mortality rates in recent years [10]. 
The nutritional aspects of mothers that may affect breast milk composition are actual food intake, nutritional reserves, and impairment in nutritional use. Changes in maternal nutritional status that alter the composition and quality of breast milk that can have a positive, neutral or negative impact on breastfed infants. When nutritional intake is reduced in nutrients in breast milk and the volume of breast milk does not change then the nutrients for the synthesis of breast milk taken from the mother's reserve or maternal tissue. The composition of breast milk is not constant and some physiological factors play a direct and indirect role. Physiological factors include breastfeeding, time, breastfeeding, nutritional status of acute mother and contraceptive pill. Non-physiological factors include environmental aspects, cigarette and alcohol consumption $[11,12]$.

Calcium is the most abundant mineral in bones and teeth because of its role in bone and tooth formation, so breastfeeding mothers are encouraged to increase calcium intake by $200 \mathrm{mg} /$ day to $1300 \mathrm{mg} /$ day [13]. The results of research by Jarjou et al [8], using an observational longitudinal study design study with 30 samples. Finding that a low calcium intake from food produces low amounts of low milk calcium as well. Calcium intake approximates the estimated biological needs for bone mineral expansion. The relationship between calcium intake and growth is largely produced by breast milk intake. This suggests that a low calcium intake does not limit the poor growth factor.

Assessment of nutritional status of pregnant and lactating mothers includes anthropometric and biochemical measurements. Nutritional status of breastfeeding mother can be measured by anthropometry index that is combination of several parameters such as measurement of body weight, height, upper arm circumference and body mass index that is body weight divided by height squared [14]. The research done in general using dietary recall method and anthropometry but not yet equipped with biochemical analyzes such as micronutrients of calcium. Therefore, in this study, besides using dietary recall, biochemical analysis was also performed. Based on the data that has been presented, the purpose of this study was to determine the difference in calcium concentration in breast milk between good nutritional status and Chronic Energy deficiency in postpartum mothers.

\section{METHODOLOGY}

The research design used was cross sectional study design by measuring the independent variable and the dependent variable being studied at the same time. The population in this study were all postpartum mothers in hospitals and puskesmas. Number of sample is 40 people with purposive sampling technique that fulfill the inclusion criteria that is normal maternity mother with good nutrition criteria that is by normal LiLA measurement, normal maternity mother with bad nutrition criteria that is with measurement of LiLA at risk Chronic energy deficiency, Age of pregnancy aterm during delivery, Age reproduction of 20-35 years old, mother giving breastfeeding on demand, postpartum mother of the 14th day and mother willing to be respondent by signing informed consent which has been issued by Ethics Committee of Hasanuddin University Medical Faculty. Fourteen days after the researcher came to the respondent's house to measure BB, LILA and foodrecall 24 hours and milked milk $3 \mathrm{cc}$, done by the researcher, then ASI stored at $-20 \mathrm{oC}$ storage until $80 \mathrm{oC}$ at Laboratory of Education Hospital of Hasanuddin University of Makassar and will be checked ASI through laboratory tests using Colorimetric Assay. In this study the data is normally distributed by using statistical test of shapiro-wilk with result $\alpha>0,05$. Test analysis using Mann Whitney and Chi-Square test was processed by using SPSS For Windows 20.

\section{RESULTS AND DISCUSSION}

Differences in Age, Parity, Intake of Calcium and IMT Respondents with nutritional status

Characteristics of respondents in this study, the results of data processing for the age variable, it can be seen that the mother of good nutrition status with age $20-25$ years as many as 5 people $(12.5 \%)$, mothers with age $26-30$ years as many as 8 people $(20 \%)$, with age $31-35$ years as many as 7 people $(17.5 \%)$ while postpartum mother with nutritional status KEK with age $20-25$ years as many as 9 people $(22.5 \%)$, mother with age $26-30$ years as many as 6 people $(15 \%)$, mother with age $31-35$ years as many as 5 people $(12.5 \%)$ while the mother of postpartum. The normality test results show that the data is not normally distributed so that the test mann whitney and got the value $\mathrm{p}=0.292$. For more details can be seen in the following table. 
Table-1: The differences of age, parity, calcium intake and IMT respondent with nutritional status

\begin{tabular}{|c|c|c|c|c|c|}
\hline \multirow{3}{*}{ Variables } & \multicolumn{4}{|c|}{ Mother Postpartum } & \multirow{3}{*}{$p$} \\
\hline & \multicolumn{2}{|c|}{ Good nutritional status $(n=20)$} & \multicolumn{2}{|c|}{$\begin{array}{c}\text { KEK } \\
(\mathbf{N}=\mathbf{2 0})\end{array}$} & \\
\hline & $\mathbf{N}$ & $(\%)$ & $\mathbf{N}$ & $(\%)$ & \\
\hline \multicolumn{6}{|l|}{ - Age } \\
\hline $20-25$ & 5 & 12.5 & 9 & 22.5 & \\
\hline $26-30$ & 8 & 20.0 & 6 & 15.0 & 0282 \\
\hline $31-35$ & 7 & 17.5 & 5 & 12.5 & \\
\hline \multicolumn{6}{|c|}{ - $\quad$ Body Mass Index } \\
\hline Very thin & 0 & 0 & 2 & 5.0 & \\
\hline Thin & 0 & 0 & 8 & 20.0 & \\
\hline Normal & 10 & 25.0 & 10 & 25.0 & 0000 \\
\hline Fat & 7 & 17.5 & 0 & 0 & \\
\hline obesity & 3 & 7.5 & 0 & 0 & \\
\hline \multicolumn{6}{|l|}{ - $\quad$ parity } \\
\hline primiparas & 7 & 17.5 & 7 & 17.5 & 1,000 \\
\hline multiparas & 13 & 32.5 & 13 & 32.5 & \\
\hline \multicolumn{6}{|c|}{ - Calcium intake } \\
\hline Good & 6 & 15.0 & 2 & 5.0 & 0048 \\
\hline Less & 14 & 35.0 & 18 & 45.0 & \\
\hline
\end{tabular}

Source: Primary Data, 2017

Distribution of respondents based on postpartum mother with good nutritional status with very thin and skinny IMT, 10 people (25\%), BMI IMT as many as 7 people $(7.5 \%)$, obesity IMT as many as 3 people $(7.5 \%)$. While postpartum mother status Chronic energy deficiency with IMT is very thin as many as 2 people (5\%), BMT Skinny as many as 8 people (20\%), Normal IMT counted 10 people $(25 \%)$, BMI obesity and obesity is not present. Normality test results show that data is not normally distributed so that tested mann whitney and got value $\mathrm{p}=0.000$.

Distribution of respondents based on the parity of postpartum mother primipara good nutrition status as many as 7 people (17.5\%), postpartum mother good multiparent nutritional status as many as 13 people $(32.5 \%)$ while with primipara KEK postpartum as many as 7 people $(17.5 \%)$ and multipara KEK postpartum mother 13 people $(32.5 \%)$.

Distribution of respondents on the basis of occupation for the good nutritional status of mothers who work as many as 7 people $(17.5 \%)$, mothers who do not work 13 people $(32.5 \%)$ whereas in postpartum mothers with nutritional status KEK working as many as 4 people $(10 \%)$, working as many as 16 people (40\%). Normality test results showed abnormally distributed data so that tested mann whitney and got value $\mathrm{p}=1,000$.

The distribution of respondents with calcium intake based on food recall was found by postpartum mother with good nutrient status with good calcium intake of 6 people $(15 \%)$ and postpartum mother with good nutritional status with less calcium intake as much as 2 people (5\%), while postpartum KEK mother with good calcium intake as many as 14 people $(35 \%)$ and SEZ postpartum women with less calcium intake as many as 18 people (45\%). Normality test results show that data is not normally distributed so that tested mann whitney and got value $\mathrm{p}=0.048$. The next description of the mother of good nutrition status as many as 20 people $(50 \%)$ and the mother of chronic energy deficiency status of 20 people $(50 \%)$.

\section{Differences in Age, Parity, Calcium and IMT Intake Respondents with calcium concentrations}

Based on the results of data analysis Different characteristics of respondents with calcium concentration ASI based on median value in this study, the results of data processing for the age variable, it can be seen that postpartum mother with high breast milk calcium concentration with age 20-25 years as many as 6 people $(15.0 \%$, mothers aged $26-30$ years as many as 7 people $(17.5 \%)$, mothers aged $31-35$ years as many as 8 people $(20.0 \%)$ note that postpartum mother with low calcium milk concentration with age 20-25 years as many as 8 people $(20.0 \%)$, mothers aged $26-30$ years as many as 7 people (17.5\%), mothers aged $31-35$ years as many as 4 people $(10.0 \%)$ Normality test results show abnormally distributed data so that tested mann whitney and got value $p=0.134$. For more details can be seen in Table-2. 
Surya Indah Nurdin et al., Haya: Saudi J. Life Sci., Vol-3, Iss-5 (May, 2018): 447-453

Table-2: Different Age, Parity, calcium intake and IMT Respondent with calcium concentration

\begin{tabular}{|c|c|c|c|c|c|}
\hline \multirow{3}{*}{ variables } & \multicolumn{4}{|c|}{ Calcium concentration of Breast Milk (ASI) } & \multirow{3}{*}{$p$} \\
\hline & \multicolumn{2}{|c|}{ High } & \multicolumn{2}{|c|}{ Low } & \\
\hline & $\mathbf{N}$ & $(\%)$ & $\mathbf{N}$ & $(\%)$ & \\
\hline \multicolumn{6}{|l|}{ - Age } \\
\hline $20-25$ & 6 & 15.0 & 8 & 6.6 & \\
\hline $26-30$ & 7 & 17.5 & 7 & 17.5 & 0134 \\
\hline $31-35$ & 8 & 20.0 & 4 & 5.7 & \\
\hline \multicolumn{6}{|c|}{ - $\quad$ Body Mass Index } \\
\hline Very thin & 0 & 0 & 2 & 5.0 & \\
\hline Thin & 3 & 7.5 & 5 & 12.5 & \\
\hline Normal & 10 & 25.0 & 10 & 25.0 & 0022 \\
\hline Fat & 6 & 15.0 & 1 & 2.5 & \\
\hline obesity & 2 & 5.0 & 1 & 2.5 & \\
\hline primiparas & 8 & 20.0 & 6 & 15.0 & 0670 \\
\hline multiparas & 13 & 32.5 & 13 & 32.5 & \\
\hline \multicolumn{6}{|c|}{ - Calcium intake } \\
\hline Good & 5 & 12.5 & 3 & 7.5 & 0755 \\
\hline Less & 16 & 40.0 & 16 & 40 & \\
\hline
\end{tabular}

Distribution of respondents based on the difference of respondent's characteristic with calcium milk concentration based on median value in this study, the result of data processing for parity variable with high calcium breastfeed concentration, primiparous postpartum mother of 8 people $(20.0 \%)$, postpartum mutlipara mother 13 persons $(32.5 \%)$. While the concentration of low milk calcium in primipara as many as 6 people $(15.0 \%)$ and multipara as many as 13 people $(32.50 \%)$. Normality test results show that data is not normally distributed so tested mann whitney and got value $\mathrm{p}=0.670$.

Distribution of respondent difference of respondent characteristic with ASI calcium concentration based on median value in this research, the result of data processing for food calcium intake variable with high calcium breastfeeding concentration, good postpartum mother as much as 5 people $(12.5 \%)$, less intake as much as 16 people $40.0 \%$ ). While low calcium milk concentration with good intake of 3 people $(7.5 \%)$ and less intake as much as 16 people $(40 \%)$. Normality test results showed abnormally distributed data so that tested mann whitney and got value $\mathrm{p}=0.755$.

Distribution of respondents based on postpartum mother with high calcium breastfeeding concentration with very skinny IMT did not exist, IMT was as thin as 3 people (7.5\%), and normal BMI as many as 10 people (25\%), fat IMT 6 people $(15.0 \%)$ and BMI Obesity as many as 2 people (5\%). While postpartum mother with low BMI calcium concentration with very thin IMT as many as 2 people (5\%), BMI as many as 5 people $(12.5 \%)$, normal BMI of 10 people $(25 \%)$, fat IMT 1 person $(2.5 \%)$ and BMI obese as much as 1 person (2.5\%). Normality test results show that data is not normally distributed so that the test mann whitney and obtained $\mathrm{p}$ value $=0.022$.

\section{Mean Differences of Breast Milk Calcium Concentration between good nutritional status and postpartum KEK mothers \\ The result of measurement of breast milk} calcium concentration between good nutritional status and postpartum mother to 40 respondent there was significant difference. In postpartum mother good nutritional status is $2.2050 \pm 1.09413 \mathrm{mg} / \mathrm{L}$ while in postpartum mother nutritional status KEK is $1.5293 \pm$ $8.86170 \mathrm{mg} / \mathrm{L}$. These results show that the mean calcium concentration of breast milk in postpartum nutrition status is well higher than that of SEZ nutrition postpartum status. For more details can be seen in the following table. 
Table-3: Comparison of breast milk calcium concentration between good nutrition and KEK Status in Mothers Postpartum

\begin{tabular}{|c|c|c|c|c|}
\hline \multirow{2}{*}{ Nutritional status } & \multicolumn{5}{|c|}{$\begin{array}{c}\text { Calcium concentration } \\
\text { (Mg / L) }\end{array}$} \\
\cline { 2 - 4 } & $\mathbf{N}$ & Mean \pm SD & median & $\boldsymbol{P}$ \\
\hline Good & 20 & $2.2050 \pm 1.09413$ & 1.7785 & \\
\hline KEK & 20 & $1.5293 \pm 8.86170$ & 1.0892 & 0025 \\
\hline Total & $\mathbf{4 0}$ & & & \\
\hline \multicolumn{5}{|c|}{ Note: Mann Whitney } \\
Source: Primary Data, 2017
\end{tabular}

The result of statistic test with Mann Whitney $\mathrm{U}$ showed the value of $\mathrm{p}=0,025$ ( $\mathrm{p}<0,05)$, meaning that there is a significant difference of calcium concentration between postpartum of good nutrition status and SEZ at postpartum.

Relationship of high calcium milk concentration with good nutritional status

Based on the results of research from 40 respondents with good nutrition status with high concentration as many as 15 people $(37.5 \%)$. While the nutritional status KEK with low calcium milk concentration as much as 5 people $(12.5 \%)$. Then the results of analysis also show the value of $\mathrm{p}=0.011$ (a $<0.05)$ there is a relationship between the two variables and the value of OR: 7.0 which means high calcium concentration of breast milk 7.0 times more at risk of good nutritional status in postpartum mothers who have high calcium breastfeeding concentration compared postpartum mothers who had low calcium breastfeeding consentration with Convidence Interval (95\% CI: 1.739-28.174) in postpartum mothers. For more details can be seen in the following table.

Table-4: The Relation between high calcium concentration of Breast Milk with Good Nutritional Status

\begin{tabular}{|c|c|c|c|c|c|c|c|}
\hline \multirow{3}{*}{ Nutrition status of Mather Postpartum } & \multicolumn{4}{|c|}{ Calcium Concentration } & \multirow{3}{*}{$\boldsymbol{P}$} & \multirow{3}{*}{ OR } & \multirow{3}{*}{$\begin{array}{l}\text { interval Confidence } \\
\text { (CI) } 95 \%\end{array}$} \\
\hline & \multicolumn{2}{|c|}{ High } & \multicolumn{2}{|c|}{ Low } & & & \\
\hline & $\mathbf{N}$ & $\%$ & $\mathbf{N}$ & $\%$ & & & \\
\hline Good & 15 & 37.5 & 5 & 12.5 & \multirow[t]{2}{*}{0011} & \multirow[t]{2}{*}{7.0} & \multirow[t]{2}{*}{$1739-28174$} \\
\hline KEK & 6 & 15.0 & 14 & 35.0 & & & \\
\hline
\end{tabular}

This study shows the results of measurement of calcium milk concentration between good nutritional status and chronic energy deficiency of postpartum mother to 40 respondents there are significant differences. Result of statistic test with Mann whitney $\mathrm{U}$ showed $\mathrm{p}$ value $=0,025(\mathrm{p}<0,05)$, mean there is difference of calcium concentration which is very significant between maternal of good nutrition status and SEZ at postpartum. The results of this study provide an overview based on age seen the average age of respondents who nutritional status KEK aged 27 years and mother with good nutritional status aged 29 years.

Judging from the level of education, most of the respondents are in high school education level, both mothers with good nutritional status and SEZ, and at higher education level of mothers with better nutritional status than mothers with nutritional status KEK. Education level determines whether or not a person is easy to understand and absorb information. But in this study the educational factor is not too constraining, because the mother can receive and do what is informed about the importance of calcium.
Viewed from parity, most of the respondents were higher in multiparity compared to primipara in both nutritional status and nutritional status of SEZ. Sampling in this study from parity looking for SEZ parity partnership and nutritional status is good due to the accuracy of data.

Distribution of respondents with calcium intake based on foodrecall was found postpartum good nutrition status with good calcium intake as much as 6 people $(30 \%)$ and postpartum good nutrition status with less calcium intake as many as 14 people $(70 \%)$, while SEZ month pregnant women with good calcium intake as many as 2 people (10\%) and SEZ dilated women with intake of less than 18 people $(90 \%)$. Result of statistic test with Mann Whitney U showed $\mathrm{p}$ value = $0,001$ ( $p<0,05)$, mean there is difference of calcium concentration which is very significant between maternal status of good nutrition status and SEZ at postpartum.

This study is in line with research by Jarjou et al [8], using an observational longitudinal study design study with 30 samples. Finding that a low calcium intake from food produces low amounts of low milk calcium as well. Calcium intake approximates the 
estimated biological needs for bone mineral expansion. The relationship between calcium intake and growth is largely produced by breast milk intake. This suggests that a low calcium intake does not limit the poor growth factor.

The results of the study by Ogechi et al, with cross-sectional design was performed on 240 randomly selected women. Use BMI to assess nutritional status with height and weight. Food intake was assessed using a 24-hour recall. Correlation data were found between nutritional status and energy intake $(p=0.793)$. Breastfeeding is a major source of concern for developing countries because it is positive. Impact on children's health and nutrition. Adequate nutrition for mothers is critical for their health as well as for their offspring [15]. Result of research of Pujiastuti [14], using correlational design with cross sectional approach with sample 54 people got result that nursing mother with malnutrition will influence breastfeed sufficiency because body need enough nutrients to produce milk, but body does not fulfill so that nutrient taken from the mother's body and result in the longer the mother will experience nutritional status that gets worse.

This result is not in line with the research conducted by Li et al., [6], with cross sectional study design that categorizes breastfeeding expenditure stages into 3 , ie 5 to 17 day transition sample 56, early 18-56 sample number 75 people and matur ie 4 to 6 months with a sample size of 103 people. Examining 11 minerals on breast milk including calcium milk. Obtain mineral concentrations such as calcium and magnesium, copper, iron, and zinc are not affected by maternal intake or nutritional status.

Proteins, carbohydrates, and fats come from synthesis in the breast gland and transfer from plasma to breast milk, while vitamins and minerals originate from transfer to breast milk. All physiological and biochemical phenomena affecting the composition of breast milk can be modified by hormones, which affect the synthesis in the breast gland. The maternal nutritional aspects that can affect the composition of breast milk are aspects of food, nutritional reserves, and disturbances in the use of maternal nutrients that change the composition of breast milk can have a positive, neutral or negative impact on breastfed babies. If the mother's nutritional intake is reduced but the level of nutrients in breast milk and the volume of breast milk does not change then the nutrients for the synthesis of breast milk taken from the mother's reserve or maternal tissue.

Calcium in the body will work effectively after the skin is exposed to a brief sting of ultraviolet $\beta$-ray radiation, because exposure to sunlight can stimulate the production of vitamin $\mathrm{D}$. This vitamin serves as a calcium opener into the bloodstream. Until finally united in the bone. But in general people avoid the sun because of fear of black so it is suspected this became one of the causes of high cases of osteoporosis in Indonesia, whereas Indonesia including the tropics. These fears are coupled with the lifestyles of people living in urban areas with little sunlight [16].

Calcium is obviously necessary for growth because it is an important part in bone and tooth formation. Also needed in smaller amounts to support the function of cells in the body. Japanese research shows that people who eat a diet low in calcium is shorter than an adequate calcium diet. Low-calcium diet means low protein, and protein is also needed for growth including bone formation. But clearly it can not be proven that calcium deficiency causes growth failure due to many factors that affect it. In the period of bone size growth, calcium content and calcium requirements increase. After the growth stops the possibility of a phase where the addition of bone and calcium together will continue to grow until the age of about 30 years [16].

Based on the results of the analysis the researchers assume that the intake of good will increase the concentration of calcium, both in postpartum mother with good nutritional status and chronic energy deficiency. Giving intake in this study needs to be accompanied by improved nutritional status for chronic energy deficient moms to increase calcium concentration, because otherwise the body will be taking calcium from bone and will have a long-term impact if it continues. Calcium removal from bone is caused by a lot of demand while breastfeeding but is not well supplied with adequate food intake and reduced food reserves in the body to exacerbate the nutritional state of breastfeeding mothers.

\section{CONCLUSION}

Based on the result of the research, it is concluded that the mean of calcium milk concentration in postpartum mother of nutritional status of SEZ is lower than the mean of calcium concentration of ASI on good nutritional status, thus higher risk of malnutrition (KEK). This research shows that postpartum mothers who have decreased the concentration low (median $166.7 \mathrm{mg} / \mathrm{L}) 7.0$ times more at risk of malnutrition (KEK) than mothers in postpartum with good nutritional status. Provision of calcium in postpartum mother of good nutritional status and nutritional status of chronic energy deficiency from pregnancy to postpartum in increasing calcium ASI postpartum mother considering the postpartum mother requires calcium for the breastfeeding period and the growth and development of her baby.

\section{REFERENCES}

1. Chang, N., Jung, J. A., Kim, H., Jo, A., Kang, S., Lee, S. W., ... \& Jung, B. M. (2015). Macronutrient composition of human milk from Korean mothers of full term infants born 
at 37-42 gestational weeks. Nutrition research and practice, 9(4), 433-438.

2. Rohmah \& Sina. (2014). Faktor- Faktor Yang Mempengaruhi Kejadian Penyapihan Kurang dari 2 Tahun Di Posyandu Sawahan Desa Didodadi Kecamatan Majayan Kabupaten Madiun. Jurnal Delima Harapan 12. 1 2014, 33-40.

3. Sakti, R. E., Hadju, V., \& Rochimiwati, S. N. (2013). Hubungan Pola Pemberian MP-ASI dengan Status Gizi Anak Usia 6-23 Bulan di Wilayah Pesisir Kecamatan Tallo Kota Makassar Tahun 2013. Jurnal MKMI K, 21109274, 0-2.

4. Segura, S. A., Ansótegui, J. A., \& DíazGómez, N. M. (2016). The importance of maternal nutrition during breastfeeding: Do breastfeeding mothers need nutritional supplements?. Anales de Pediatría (English Edition), 84(6), 347-e1.

5. Perrin, M. T., Fogleman, A. D., Newburg, D. S., \& Allen, J. C. (2017). A longitudinal study of human milk composition in the second year postpartum: implications for human milk banking. Maternal \& child nutrition, 13(1).

6. Li, C., Solomons, N. W., Scott, M. E., \& Koski, K. G. (2016). Minerals and Trace Elements in Human Breast Milk Are Associated with Guatemalan Infant Anthropometric Outcomes within the First 6 Months-3. The Journal of nutrition, 146(10), 20672074.

7. Ministry of Health RI. (2015). Health within the framework of sustainable development goals. Jakarta. Secretariat of health development post 2015 health ministry of the Republic of Indonesia.

8. Jarjou, L. M. A., Goldberg, G. R., Coward, W. A., \& Prentice, A. (2012). Calcium intake of rural Gambian infants: a quantitative study of the relative contributions of breast milk and complementary foods at 3 and 12 months of age. European journal of clinical nutrition, 66(6), 673.

9. Pujiastuti, N. (2010). Korelasi Antara Status Gizi Ibu Menyusui dengan Kecukupan ASI di Posyandu Desa Karang Kedawang Kecamatan Sooko Kabupaten Mojokerto. Jurnal Keperawatan, 1(2)

10. Takimoto, H., Yoshiike, N., Katagiri, A., Ishida, H., \& Abe, S. (2003). Nutritional status of pregnant and lactating women in Japan: A comparison with non-pregnant/non-lactating controls in the National Nutrition Survey. Journal of obstetrics and gynaecology research, 29(2), 96-103.

11. Rahmawati, E., \& Proverawati, A. (2010). Kapita selekta ASI dan menyusui. Yogyakarta: Nuha Medika.
12. Kolasa, K. M., Firnhaber, G., \& Haven, K. (2015). Diet for a healthy lactating woman. Clinical obstetrics and gynecology, 58(4), 893901.

13. Fikawati, S., Syafiq, A., \& Karima, K. (2015). Gizi ibu dan bayi. Jakarta: Rajawali Pers.

14. Pujiastuti, N. (2010). Korelasi Antara Status Gizi Ibu Menyusui dengan Kecukupan ASI di Posyandu Desa Karang Kedawang Kecamatan Sooko Kabupaten Mojokerto. Jurnal Keperawatan, 1(2).

15. Ogechi, U. P. (2014). A study of the nutritional status and dietary intake of lactating women in Umuahia, Nigeria. Am J Health Res, 2(1), 20.

16. Theobald, H. E. (2005). Dietary calcium and health. Nutrition Bulletin, 30(3), 237-277. 